$J N M-D-14-01212$

\title{
Synthesis, characterization and thermochemistry of Cs-, Rb- and Sr- substituted barium aluminium titanate hollandites
}

\author{
H. $\mathrm{Xu}^{1, *}, \mathrm{~L} . \mathrm{Wu}^{2}, \mathrm{~J} . \mathrm{Zhu},{ }^{3}$ and A. Navrotsky ${ }^{2}$ \\ ${ }^{1}$ Earth and Environmental Sciences Division, ${ }^{3}$ Los Alamos Neutron Science Center, Los Alamos \\ National Laboratory, Los Alamos, New Mexico 87545, USA \\ ${ }^{2}$ Peter A. Rock Thermochemistry Laboratory and NEAT ORU, University of California at Davis, \\ Davis, California 95616, USA \\ *Email: hxu@lanl.gov
}

Submitted to Journal of Nuclear Materials

Submitted in November 2014

Revised in December 2014

1

(C) 2015. This manuscript version is made available under the Elsevier user license http:/www.elsevier.com/open-access/userlicense/1.0/ 


\section{ABSTRACT}

Titanate hollandites are of considerable interest for immobilization of radioactive Cs, its daughter product $\mathrm{Ba}$ and related radionuclides $\mathrm{Rb}$ and $\mathrm{Sr}$. In this study, we synthesized three hollandites, $\mathrm{Ba}_{1.18} \mathrm{Cs}_{0.21} \mathrm{Al}_{2.44} \mathrm{Ti}_{5.53} \mathrm{O}_{16}, \mathrm{Ba}_{1.17} \mathrm{Rb}_{0.19} \mathrm{Al}_{2.46} \mathrm{Ti}_{5.53} \mathrm{O}_{16}$ and $\mathrm{Ba}_{1.14} \mathrm{Sr}_{0.10} \mathrm{Al}_{2.38} \mathrm{Ti}_{5.59} \mathrm{O}_{16}$, using sol-gel methods. Rietveld analysis of synchrotron XRD data shows that they adopt the tetragonal structure (space group $I 4 / \mathrm{m}$ ), and their cell parameters increase with increasing cation

size $\left(\mathrm{Sr}^{2+} \rightarrow \mathrm{Rb}^{+} \rightarrow \mathrm{Cs}^{+}\right)$. Standard enthalpies of formation of these hollandites were determined from drop solution calorimetric measurements with lead borate as the solvent at $973 \mathrm{~K}$. Their formation enthalpies are similar, consistent with the occurrence of extensive cation substitutions in hollandites. Further energetic analysis with respect to $\mathrm{BaTiO}_{3}$ and $\mathrm{SrTiO}_{3}$ perovskites and other oxides reveals decreased thermodynamic stability from Cs- to Rb- to Sr-hollandite. This trend is consistent with the phase assemblage observed in Synroc, where $\mathrm{Cs}^{+}, \mathrm{Rb}^{+}$and $\mathrm{Ba}^{2+}$ enter into hollandite, whereas $\mathrm{Sr}^{2+}$ occurs in perovskite.

\section{KEYWORDS}

Hollandite; Crystal structure; Phase stability; Synchrotron X-ray diffraction; High-temperature oxide melt solution calorimetry 


\section{Introduction}

Titanate hollandites, either as a ceramic or as a component of the Synroc assemblage, are potential host phases for immobilization of radioactive alkali and alkaline earth elements [1-2]. Titanate hollandites exhibit a wide range of compositions, $\mathrm{A}_{\mathrm{x}}\left(\mathrm{Ti}^{4+}{ }^{4+} \mathrm{B}\right)_{8} \mathrm{O}_{16},\left(\mathrm{~A}=\mathrm{Ba}^{2+}, \mathrm{Cs}^{+}, \mathrm{Rb}^{+}\right.$, $\left.\mathrm{Sr}^{2+} ; \mathrm{B}=\mathrm{Al}^{3+}, \mathrm{Fe}^{3+}, \mathrm{Mg}^{2+}, \mathrm{Ti}^{3+}, \mathrm{Cr}^{3+}\right)$ [3-13], and are structurally analogous to the prototype hollandite, $\mathrm{Ba}\left(\mathrm{Mn}^{4+}, \mathrm{Mn}^{2+}\right)_{8} \mathrm{O}_{16}[14-15]$. In the structure, $\left[\mathrm{TiO}_{6}\right]$ and $\left[\mathrm{BO}_{6}\right]$ octahedra are linked via edge and corner sharing to form a three dimensional framework, which contains one dimensional tunnels parallel to the c-axis (for tetragonal hollandites) (Fig. 1a) or b-axis (for monoclinic hollandites). The extra-framework cations $\left(\mathrm{A}^{+}\right.$or $\left.\mathrm{A}^{2+}\right)$ occupy the box-shaped cavity sites, each coordinated by eight oxygen atoms, within the structural tunnels. This structure is tolerant of cation substitutions over both $\mathrm{A}$ and $\mathrm{Ti} / \mathrm{B}$ sites, resulting in rich chemistry of the hollandite family. This characteristic makes hollandites capable of incorporating multiple radionuclides such as ${ }^{137} \mathrm{Cs}$ and its decay product ${ }^{137} \mathrm{Ba}$ - an advantageous attribute of glass waste forms but relatively rare in crystalline host phases. Depending on the mean radius ratio of $\mathrm{A}$ and Ti/B cations, the structure may adopt a tetragonal (space group $I / / m$ ) or monoclinic (space group $I 2 / m$ ) symmetry $[3,10]$. In the tetragonal structure, all octahedral Ti/B sites are identical and the cross section of the tunnels is approximately square shaped (Fig. 1b). In the monoclinic structure, two types of octahedral sites are present, and the cross section of the tunnels is rhombus shaped. The reduction in symmetry $(I 4 / m \rightarrow I 2 / m)$ arises from a shear-type collapse of the tunnels, presumably because the A cation is not large enough to hold open the expanded tetragonal $\left[\left(\mathrm{Ti}^{4+}, \mathrm{B}\right) \mathrm{O}_{6}\right]$ framework.

To develop hollandite based ceramic waste forms, numerous studies have been conducted, including their syntheses and characterization [3,16-19], radiation damage measurements [20-21] 
and leach tests [22-24]. However, there was no information on the thermodynamic stability of titanate hollandites until recently [11]. Measuring thermodynamic properties of hollandites is important in assessing their suitability as radionuclide host phases, especially in the context of high heats generated due to radioactive decay. In our recent study [11], we performed thermochemical measurements of three substituted barium titanium hollandites, in which part of the $\mathrm{Ti}^{4+}$ cations are replaced by $\mathrm{Al}^{3+}, \mathrm{Fe}^{3+}$ and $\mathrm{Mg}^{2+}$ over the framework sites, using hightemperature oxide melt solution calorimetry; our results indicate that Al- and Fe-substituted hollandites are stable relative to phase assemblages containing $\mathrm{BaTiO}_{3}$ perovskite, $\mathrm{Al}_{2} \mathrm{O}_{3}$ or $\mathrm{Fe}_{2} \mathrm{O}_{3}$ and $\mathrm{TiO}_{2}$, whereas $\mathrm{Mg}$-hollandite is unstable with respect to an assemblage of $\mathrm{BaTiO}_{3}$ perovskite, $\mathrm{MgTiO}_{3}$ ilmenite and $\mathrm{TiO}_{2}$ and thus is not an appropriate waste form candidate [11]. The focus of this study is on the effects of tunnel cation substitution (A cations) on the hollandite structure and stability. This is important for evaluating the suitability of hollandites as a host for multiple radionuclides and their decay products. For example, when ${ }^{137} \mathrm{Cs}$ transforms to ${ }^{137} \mathrm{Ba}$ through beta decay with a half-life of $\sim 30$ years, the ability to accommodate both Cs and $\mathrm{Ba}$ in the hollandite structure ensures its stability over the decay period and beyond. Since our previous thermochemical study demonstrated that Al-substituted hollandites are thermodynamically stable [11], in this work, we studied hollandite phases that have the same $\mathrm{Al} / \mathrm{Ti}$ (B cations) stoichiometries but differ in A cation species $\left(\mathrm{Cs}^{+}, \mathrm{Rb}^{+}\right.$and $\left.\mathrm{Sr}^{2+}\right) . \mathrm{Specifically}$ three hollandite phases, $\mathrm{Ba}_{1.18} \mathrm{Cs}_{0.21} \mathrm{Al}_{2.44} \mathrm{Ti}_{5.53} \mathrm{O}_{16}, \mathrm{Ba}_{1.17} \mathrm{Rb}_{0.19} \mathrm{Al}_{2.46} \mathrm{Ti}_{5.53} \mathrm{O}_{16}$ and $\mathrm{Ba}_{1.14} \mathrm{Sr}_{0.10} \mathrm{Al}_{2.38} \mathrm{Ti}_{5.59} \mathrm{O}_{16}$, were synthesized using sol-gel methods. Powder synchrotron X-ray diffraction (XRD) combined with Rietveld analysis was conducted to characterize their crystal structures. High-temperature oxide melt solution calorimetry with molten lead borate as solvent was used to determine their enthalpies of formation from constituent oxides and their enthalpies 
relative to other possible phase assemblages. The obtained stability relations are discussed in relation to crystal chemistry and in the context of $\mathrm{Cs} / \mathrm{Rb} / \mathrm{Sr} / \mathrm{Ba}$ immobilization.

\section{Experimental methods}

\subsection{Sample synthesis}

Three hollandite samples with the compositions $\mathrm{Ba}_{1.18} \mathrm{Cs}_{0.21} \mathrm{Al}_{2.44} \mathrm{Ti}_{5.53} \mathrm{O}_{16}$, $\mathrm{Ba}_{1.17} \mathrm{Rb}_{0.19} \mathrm{Al}_{2.46} \mathrm{Ti}_{5.53} \mathrm{O}_{16}$ and $\mathrm{Ba}_{1.14} \mathrm{Sr}_{0.10} \mathrm{Al}_{2.38} \mathrm{Ti}_{5.59} \mathrm{O}_{16}$, were synthesized using a sol-gel route. $\mathrm{Cs}_{2} \mathrm{CO}_{3}, \mathrm{RbNO}_{3}, \mathrm{Ba}(\mathrm{OAc})_{2}, \mathrm{Sr}(\mathrm{OAc})_{2}, \mathrm{Al}(\mathrm{O} \text {-sec-butyl })_{3}$, and $\mathrm{Ti}\left(\mathrm{OC}_{3} \mathrm{H}_{7}\right)_{4}$ were used as starting chemicals. In a typical procedure, for example, for the synthesis of $\mathrm{Ba}_{1.18} \mathrm{Cs}_{0.21} \mathrm{Al}_{2.44} \mathrm{Ti}_{5.53} \mathrm{O}_{16}$, the $\mathrm{Al}$ and Ti reagents in the targeted stoichiometric ratio were first dissolved in absolute ethanol in a dry beaker, and the $\mathrm{Cs}$ and Ba reagents were dissolved in acetic acid in another beaker. After the solid powders were fully dissolved, the latter solution was added to the former, and the mixed solution was stirred and heated at about $353 \mathrm{~K}$ for 3-4 h. During this process, the solution first became clear, and then the solvent evaporated, producing a transparent gel. Next, the gel was heated in a Pt crucible at $973 \mathrm{~K}$ for $2 \mathrm{~h}$ to remove all the organic components, followed by calcination at $1373 \mathrm{~K}$ for $2 \mathrm{~h}$. The heat treatment temperatures were deduced from differential scanning calorimetry - thermogravimetry (DSC-TG) measurements of the gel precursors to 1473 $\mathrm{K}$ at $10 \mathrm{~K} / \mathrm{min}$ in air with a flushing gas flow rate of $20 \mathrm{~cm}^{3} / \mathrm{min}$ using a Setaram Labsys instrument. The Rb- and Sr-substituted hollandite samples were synthesized using the same procedures, except that the final calcination temperature of their gel precursors was $1273 \mathrm{~K}$. The obtained samples were crystalline and phase pure, as revealed by powder XRD (Bruker-AXS $\mathrm{D} 8, \mathrm{CuK} \alpha$ radiation, $40 \mathrm{keV}$ and $40 \mathrm{~mA}$ ). Note that a number of previous studies used solid-state oxide sintering ("oxide route", [3]), rather than sol-gel methods (similar to "alkoxide route" [3]), 
to synthesize hollandite phases. Sol-gel synthesis generally has the advantage of producing more homogeneous and phase pure samples at lower temperatures and/or for shorter periods of time because component cations are well mixed in the precursor solutions.

\subsection{Electron microprobe analysis}

The compositions and homogeneity of the synthesized samples were analyzed using a Cameca SX100 electron microprobe operated at an accelerating voltage of $15 \mathrm{keV}$ and a beam current of $20 \mathrm{nA}$. Wavelength dispersive spectroscopy (WDS) was used to determine the amounts of $\mathrm{Ba}, \mathrm{Ti}, \mathrm{Al}, \mathrm{Cs}, \mathrm{Rb}$ and $\mathrm{Sr}$, with $\mathrm{BaTiO}_{3}, \mathrm{TiO}_{2}, \alpha-\mathrm{Al}_{2} \mathrm{O}_{3}, \mathrm{CsCl}, \mathrm{RbTiO}\left(\mathrm{PO}_{4}\right)$ and $\mathrm{SrTiO}_{3}$ as standards, respectively. Back-scattered electron (BSE) imaging was used to check the sample homogeneity.

\subsection{Powder synchrotron X-ray diffraction and Rietveld analysis}

Powder synchrotron XRD measurements of the three hollandite phases were conducted at the 16BM-D beamline of the Advanced Photon Source (APS), Argonne National Laboratory, with a wavelength of $0.413272 \AA$. Sample powders were smeared into a thin layer on a plate, and the data were collected from $2^{\circ}$ to $28.5^{\circ} 2 \theta$.

The synchrotron data were analyzed using the Rietveld method with the General Structure Analysis System (GSAS) program [25]. The starting structural parameters were taken from the study of hollandite compounds by Cheary [5], and the site occupies of $\mathrm{Ba}, \mathrm{Cs}, \mathrm{Rb}, \mathrm{Sr}, \mathrm{Al}$ and $\mathrm{Ti}$ were fixed at the stoichiometries determined by electron microprobe analysis. The refinements proceeded as follows: After the scale factor and four background terms (shifted Chebyshev function) had converged, specimen displacement and lattice parameters were added and optimized. Eight or ten additional background terms were then added, and the peak profiles were fitted to pseudo-Voigt convolution functions with a peak asymmetry correction [26-27]. On 
convergence of the preceding parameters, the atomic coordinates and atomic isotropic temperature factors of $\mathrm{Ba} / \mathrm{Cs}$ or $\mathrm{Ba} / \mathrm{Rb}$ or $\mathrm{Ba} / \mathrm{Sr}, \mathrm{Al} / \mathrm{Ti}$ and $\mathrm{O}$ were refined.

\subsection{High-temperature oxide melt solution calorimetry}

High temperature oxide melt solution calorimetric experiments were performed using a custom-built Tian-Calvet microcalorimeter operating at $973 \mathrm{~K}$ with molten lead borate $\left(2 \mathrm{PbO} \cdot \mathrm{B}_{2} \mathrm{O}_{3}\right)$ as the solvent. The instrument and experimental procedure have been described in detail by Navrotsky [28]. A sample pellet weighing $\sim 5 \mathrm{mg}$ was dropped from room temperature into the solvent in the hot calorimeter. The heat effect measured includes the energy associated with heating the sample from room temperature to $973 \mathrm{~K}$ (heat content) plus the enthalpy of solution of the sample. The calorimeter was calibrated against the known heat content of $\sim 5 \mathrm{mg}$ corundum pellets. To facilitate the dissolution of the sample and to ensure that the oxidation state of $\mathrm{Ti} \mathrm{Ti}^{4+}$, was maintained during the dissolution, air was bubbled through the solvent at a rate of $7.2 \mathrm{~cm}^{3} / \mathrm{min}$ and was also flowed through the airspace above the melt at $51.6 \mathrm{~cm}^{3} / \mathrm{min}$. Nine to thirteen sample pellets were dropped for each composition.

\section{Results and discussion}

\subsection{Chemical compositions}

The chemical formulae of the Cs-, $\mathrm{Rb}$ - and $\mathrm{Sr}$-substituted hollandites determined by electron microprobe WDS analysis are $\mathrm{Ba}_{1.18} \mathrm{Cs}_{0.21} \mathrm{Al}_{2.44} \mathrm{Ti}_{5.53} \mathrm{O}_{16}, \mathrm{Ba}_{1.17} \mathrm{Rb}_{0.19} \mathrm{Al}_{2.46} \mathrm{Ti}_{5.53} \mathrm{O}_{16}$ and $\mathrm{Ba}_{1.14} \mathrm{Sr}_{0.10} \mathrm{Al}_{2.38} \mathrm{Ti}_{5.59} \mathrm{O}_{16}$, respectively, which are used for later structural refinements and thermodynamic calculations. Note that they have almost the same Ba contents and $\mathrm{Al} / \mathrm{Ti}$ (B cations) ratios, which we tried to achieve during our sample synthesis. Furthermore, BSE images (Fig. 2) reveal no phase segregation or minor phases, confirming the phase purity of the samples 
indicated by powder XRD.

\subsection{Crystal structure}

The obtained synchrotron XRD patterns of all the three substituted hollandites are consistent with that of $\mathrm{Ba}_{1.24} \mathrm{Al}_{2.48} \mathrm{Ti}_{5.52} \mathrm{O}_{16}$ hollandite with a tetragonal symmetry (space group $I 4 / m$ ) $[6,13]$; our refined structural parameters indicate the occurrence of solid solutions with part of the $\mathrm{Ba}^{2+}$ cations replaced by $\mathrm{Cs}^{+}, \mathrm{Rb}^{+}$or $\mathrm{Sr}^{2+}$. These phases have a framework structure composed of $\left[\mathrm{TiO}_{6}\right]$ and $\left[\mathrm{AlO}_{6}\right]$ octahedra linked via corner and edge sharing, with the alkali

$\left(\mathrm{Cs}^{+}, \mathrm{Rb}^{+}\right)$and/or alkaline earth $\left(\mathrm{Ba}^{2+}, \mathrm{Sr}^{2+}\right)$ cations being in eight oxygen coordination along the tunnels parallel to the c-axis (Fig. 1). These tunnel cations are usually located off the center of the square-shaped cavity of the eight oxygen atoms. Because the number of $\mathrm{Ba}^{2+}$ and $\mathrm{Cs}^{+}$or $\mathrm{Rb}^{+}$ or $\mathrm{Sr}^{2+}$ is smaller than that of their available sites, superlattices arise frequently from ordering of these cations and vacancies in the tunnels [8]. Close inspection of the obtained XRD patterns reveals very weak and broad peaks in the $2 \theta$ ranges of $5^{\circ}-6^{\circ}$ and $6.9^{\circ}-7.3^{\circ}$, consistent with an incommensurate $I 4 / m(00 \gamma) 00$ superstructure reported previously for $\mathrm{Ba} / \mathrm{Al}$ and $\mathrm{Ba} / \mathrm{Cs} / \mathrm{Al} / \mathrm{Fe}$ titanate hollandites $[3,20]$. Detailed analysis of the superstructure requires single crystal XRD data or electron diffraction patterns and thus is beyond the scope of this study. For Rietveld analysis of the synchrotron data, we excluded the superlattice peaks and used the primary $I 4 / \mathrm{m}$ structure model, which represents the averaged structure of slightly different subcells from the superstructure.

The final fitted XRD patterns are plotted in Figure 3, and the refinement agreement indices and obtained unit-cell parameters are listed in Table 1. Figure 4 plots variations of cell parameters $a, c$ and cell volume $V$ as a function of ionic radii of $\mathrm{Cs}^{+}, \mathrm{Rb}^{+}$and $\mathrm{Sr}^{2+}$ (coordinated to eight oxygen atoms). With increasing cation size (r) from $1.26 \AA$ for $\mathrm{Sr}^{2+}$ to $1.61 \AA$ for $\mathrm{Rb}^{+}$to 
$1.74 \AA$ for $\mathrm{Cs}^{+}$[29], both cell parameters $a$ and $c$ increase (approximately linearly, especially $c$ ), and thus cell volume $V$ also increases. However, it appears that the hollandite structure expands more rapidly along the a-axis than along c; the linear relations obtained by fitting the $a$ and $c$ data are: $a=0.096( \pm 0.023) r+9.812( \pm 0.036)\left(\mathrm{R}^{2}=0.945\right)$ and $c=0.021( \pm 0.001) r+2.890( \pm 0.002)$ $\left(\mathrm{R}^{2}=0.997\right)$ (Fig. 4). This behavior may be attributed to the occurrence of double chains of [(Ti,Al) $\left.\mathrm{O}_{6}\right]$ octahedra, formed via edge sharing parallel to the c-axis, which, to some extent, limits the hollandite framework flexibility along c. In addition, it is worth noting that the amounts of $\mathrm{Cs}^{+}\left(0.21\right.$ mole per hollandite formula) and $\mathrm{Rb}^{+}(0.19$ mole per formula) are about two times that of $\mathrm{Sr}^{2+}(0.10$ mole per formula) due to the requirement for charge neutrality. However, as shown in Figure 4, this difference seems to have little effect on the unit cell dimension variations. It is conceivable that for a given tunnel cation, once its content exceeds a certain amount, incorporation of additional cations in the tunnel will not result in significant further expansion of the hollandite framework. This probably also depends on the location of the cation; previous studies show that the off-center shifts of tunnel cations along $\mathbf{c}$ can vary with their sizes [6]. In short, the combined effects of the tunnel cation off-centering, order-disorder, occurrence of tunnel site vacancies, and the flexibility of $\left[(\mathrm{Ti}, \mathrm{Al}) \mathrm{O}_{6}\right]$ octahedral framework via shifting its corner-sharing oxygen, lead to the large flexibility of the hollandite structure to accommodate different cations in its tunnels.

\subsection{Thermochemistry}

The measured heats of drop solution $\left(\Delta \mathrm{H}_{\mathrm{ds}}\right)$ of the three hollandite phases in the lead borate solvent at $973 \mathrm{~K}$ are listed in Table 2 . Using these $\Delta \mathrm{H}_{\mathrm{ds}}$ data and the previously reported $\Delta \mathrm{H}_{\mathrm{ds}}$ and $\Delta \mathrm{H}_{\mathrm{f}, \mathrm{el}}{ }^{0}$ values for the constituent oxides $\mathrm{BaO}, \mathrm{Cs}_{2} \mathrm{O}, \mathrm{Rb}_{2} \mathrm{O}, \mathrm{SrO}, \mathrm{Al}_{2} \mathrm{O}_{3}$ and $\mathrm{TiO}_{2}$ (Table 3), we calculated the standard molar enthalpies of formation of the three hollandite phases from the 
oxides $\left(\Delta \mathrm{H}_{\mathrm{f}, \mathrm{ox}}{ }^{0}\right)$ and from the elements $\left(\Delta \mathrm{H}_{\mathrm{f}, \mathrm{el}}{ }^{0}\right)$ via certain thermochemical cycles (e.g., those for $\mathrm{Ba}_{1.18} \mathrm{Cs}_{0.21} \mathrm{Al}_{2.44} \mathrm{Ti}_{5.53} \mathrm{O}_{16}$ shown in Table 4). The obtained $\Delta \mathrm{H}_{\mathrm{f}, \mathrm{ox}}{ }^{0}$ and $\Delta \mathrm{H}_{\mathrm{f}, \mathrm{el}}{ }^{0}$ are presented in Table 2. As shown in Figure 5a, the $\Delta \mathrm{H}_{\mathrm{f}, \mathrm{ox}}{ }^{0}$ values for the three hollandite phases are all exothermic, indicating that they are thermodynamically stable relative to their constituent oxides. Moreover, although these values are similar, they become slightly more exothermic with increasing ionic radii of the substituted cations $\mathrm{Sr}^{2+}, \mathrm{Rb}^{+}$and $\mathrm{Cs}^{+}$. The general trend of increasing energetic stability with decreasing ionic potential $(z / r ; z$ is the formal charge of the metal cation, and $r$ is its ionic radius) or decreasing oxide basicity reflects the dominance of acid-base chemistry in phase stability [37], and has been observed in many systems including titanates and titanosilicates [38-41]. Nevertheless, the similarities among the $\Delta \mathrm{H}_{\mathrm{f}, \mathrm{ox}}{ }^{0}$ values of the three hollandite phases suggest that they have similar phase stabilities relative to their constituent oxides at standard conditions, which is consistent with the ease of Cs- $\mathrm{Rb}$-Sr substitutions in hollandites via accommodating these cations in the structural tunnels.

\subsection{Implications for radionuclide immobilization}

Although the large exothermic enthalpies of formation of the three substituted hollandites are an indication of their higher stability relative to binary oxides, for assessment of their suitability as waste forms, one must also consider their stability relative to other competing phase assemblages including ternary oxides. A conceivable phase assemblage contains $\mathrm{BaTiO}_{3}$ perovskite, $\mathrm{SrTiO}_{3}$ perovskite (for Sr-substituted hollandite) and other oxides and can be evaluated by thermodynamics using the following reactions:

$$
\begin{gathered}
\mathrm{Ba}_{1.18} \mathrm{Cs}_{0.21} \mathrm{Al}_{2.44} \mathrm{Ti}_{5.53} \mathrm{O}_{16} \rightarrow 1.18 \mathrm{BaTiO}_{3}+0.105 \mathrm{Cs}_{2} \mathrm{O}+1.22 \mathrm{Al}_{2} \mathrm{O}_{3}+5.53 \mathrm{TiO}_{2} \\
\mathrm{Ba}_{1.17} \mathrm{Rb}_{0.19} \mathrm{Al}_{2.46} \mathrm{Ti}_{5.53} \mathrm{O}_{16} \rightarrow 1.17 \mathrm{BaTiO}_{3}+0.095 \mathrm{Rb}_{2} \mathrm{O}+1.23 \mathrm{Al}_{2} \mathrm{O}_{3}+5.53 \mathrm{TiO}_{2} \\
\mathrm{Ba}_{1.14} \mathrm{Sr}_{0.10} \mathrm{Al}_{2.38} \mathrm{Ti}_{5.59} \mathrm{O}_{16} \rightarrow 1.14 \mathrm{BaTiO}_{3}+0.10 \mathrm{SrTiO}_{3}+1.19 \mathrm{Al}_{2} \mathrm{O}_{3}+5.59 \mathrm{TiO}_{2}
\end{gathered}
$$


Although $\mathrm{Al}_{2} \mathrm{TiO}_{5}$ exists at high temperature, it is not stable at ambient conditions [42] and thus is not considered here as a potential phase of hollandite decomposition. $\mathrm{CsAlO}_{2}$ and $\mathrm{RbAlO}_{2}$ are also possible phases (though they have not been reported in Synroc). However, since their enthalpies of formation are not available, and such alkali aluminates are hard to synthesize and maintain anhydrous, we will not consider them here. The enthalpies of reactions at standard conditions are calculated as follows:

$$
\begin{aligned}
& \Delta H_{r x n, C s-\text { hollandite }}=1.18 \Delta H_{f, o x\left(B a T i O_{3}\right)}-\Delta H_{f, o x\left(B a_{1.18} C s_{0.21} A l_{2.44} T i_{5.53} O_{16}\right)}=32.2 \pm 13.5 \mathrm{~kJ} / \mathrm{mol} \\
& \Delta H_{\text {rxn,Rb-hollandite }}=1.17 \Delta H_{f, o x\left(B a T i O_{3}\right)}-\Delta H_{f, o x\left(B a_{1.17} R b_{0.19} A l_{2.46} T i_{5.53} O_{16}\right)}=26.9 \pm 13.4 \mathrm{~kJ} / \mathrm{mol} \\
& \Delta H_{r x n, S r-h o l l a n d i t e}=\left(1.14 \Delta H_{f, o x\left(B_{B T i O}\right)}+0.10 \Delta H_{f, o x\left(\operatorname{SrTiO}_{3}\right)}\right)-\Delta H_{f, o x\left(B a_{1.14} S r_{0.10} A l_{2.38} T i_{5.59} O_{16}\right)}=
\end{aligned}
$$

$14.2 \pm 12.0 \mathrm{~kJ} / \mathrm{mol}$

where $\Delta \mathrm{H}_{\mathrm{f}, \mathrm{ox}}$ values of Cs-, $\mathrm{Rb}$ - and Sr-hollandite are from Table 2, $\Delta H_{f, o x\left(\mathrm{BaTiO}_{3}\right)}=-152.30 \pm$ $4.00 \mathrm{~kJ} / \mathrm{mol}[43]$, and $\Delta H_{f, o x}\left(\mathrm{SrTiO}_{3}\right)=-117.1 \pm 2.1 \mathrm{~kJ} / \mathrm{mol}[40]$.

The obtained reaction enthalpies are plotted in Figure 5b, which shows an increasing trend from Sr- to $\mathrm{Rb}$ - to Cs-hollandite. From these results, we infer that Cs- and $\mathrm{Rb}$-hollandite are energetically stable at room temperature with respect to $\mathrm{BaTiO}_{3}, \mathrm{Cs}_{2} \mathrm{O}$ or $\mathrm{Rb}_{2} \mathrm{O}, \mathrm{Al}_{2} \mathrm{O}_{3}$ and $\mathrm{TiO}_{2}$, since their reaction enthalpies are endothermic. On the other hand, Sr-hollandite may be comparable in stability to $\mathrm{BaTiO}_{3}, \mathrm{SrTiO}_{3}, \mathrm{Al}_{2} \mathrm{O}_{3}$ and $\mathrm{TiO}_{2}$, as the reaction enthalpy of its decomposition is closer to zero within experimental uncertainties. These stability relations are in general consistent with phase assemblages in Synroc that is typically produced by hot-pressing a mixture of component binary oxides, resulting in three major phases: hollandite, perovskite and zirconolite [1-2]. Generally, $\mathrm{Ba}^{2+}$ and alkali cations including $\mathrm{Cs}^{+}, \mathrm{Rb}^{+}$and $\mathrm{K}^{+}$tend to occur in hollandite, $\mathrm{Sr}^{2+}$ enters into perovskite, and actinides and rare earth elements occur in zirconolite [1-2]. Thus the decreased stability of Cs- to Rb- to Sr-hollandite with respect to $\mathrm{BaTiO}_{3}, \mathrm{SrTiO}_{3}$, 
$\mathrm{Al}_{2} \mathrm{O}_{3}$ and $\mathrm{TiO}_{2}$ is consistent with the phase relations in Synroc, where $\mathrm{Cs}^{+}, \mathrm{Rb}^{+}$and $\mathrm{Ba}^{2+}$ are incorporated into hollandite phases, whereas $\mathrm{Sr}^{2+}$ occurs in titanate perovskite.

\section{Conclusions}

Cs-, $\mathrm{Rb}$ - and Sr-substituted barium hollandites have been synthesized using sol-gel methods. Synchrotron X-ray diffraction combined with Rietveld analysis reveals that all these phases adopt the tetragonal $I 4 / m$ structure with their cell dimensions expanding with increasing cation size $\left(\mathrm{Sr}^{2+} \rightarrow \mathrm{Rb}^{+} \rightarrow \mathrm{Cs}^{+}\right)$. The standard enthalpies of formation from the constituent oxides determined by high temperature oxide melt solution calorimetry are very similar, consistent with the occurrence of extensive tunnel cation substitutions in the hollandite structure. Moreover, all the formation enthalpies are strongly exothermic, indicating that the hollandite phases are more stable than their constituent oxides at standard conditions. This is consistent with synthesis of Synroc, which contains hollandite as a major phase, from component oxides by hot-pressing. Nevertheless, further stability relation analysis of these substituted hollandites with respect to $\mathrm{BaTiO}_{3}$ and $\mathrm{SrTiO}_{3}$ perovskites and other oxides indicates that their thermodynamic stability decreases from Cs- to $\mathrm{Rb}$ - to Sr-hollandite. This trend is in agreement with the phase assemblages in Synroc, where $\mathrm{Cs}^{+}, \mathrm{Rb}^{+}$and $\mathrm{Ba}^{2+}$ are incorporated into hollandite phases, whereas $\mathrm{Sr}^{2+}$ occurs in titanate perovskite.

\section{Acknowledgments}

This work was supported by the laboratory-directed research and development (LDRD) program of Los Alamos National Laboratory, which is operated by Los Alamos National Security LLC, under DOE Contract DE-AC52-06NA25396. Use of the Advanced Photon Source 
at Argonne National Laboratory was supported by the U.S. DOE, Office of Science, Office of Basic Energy Sciences, under Contract No. DE-AC02-06CH11357.

\section{References}

[1] A. E. Ringwood, S. E. Kesson, N. G. Ware, W. O. Hibberson, and A. Major, "Immobilization of high level nuclear reactor wastes in SYNROC," Nature, 278, 219 (1979).

[2] A. E. Ringwood, S. E. Kesson, N. G. Ware, W. O. Hibberson, and A. Major, “The SYNROC process: A geochemical approach to nuclear waste immobilization,”

Geochemical Journal, 13, 141 (1979).

[3] V. Aubin-Chevaldonnet, D. Caurant, A. Dannoux, D. Gourier, T. Charpentier, L.

Mazerolles, and T. Advocat, " Preparation and Characterization of $(\mathrm{Ba}, \mathrm{Cs})(\mathrm{M}, \mathrm{Ti})_{8} \mathrm{O}_{16}(\mathrm{M}=$ $\left.\mathrm{Al}^{3+}, \mathrm{Fe}^{3+}, \mathrm{Ga}^{3+}, \mathrm{Cr}^{3+}, \mathrm{Sc}^{3+}, \mathrm{Mg}^{2+}\right)$ Hollandite Ceramics Developed for Radioactive Cesium Immobilization," J. Nucl. Materials, 366 137-160 (2007).

[4] K. R. Whittle, S. E. Ashbrook, G. R. Lumpkin, I. Farnan, R. I. Smith, and S. A. T. Redfern, "The Effect of Caesium on Barium Hollandites Studied by Neutron Diffraction and Magic-Angle Spinning (MAS) Nuclear Magnetic Resonance,” J. Mater. Sci., 42 9379-9391 (2007).

[5] R. W. Cheary, "An Analysis of the Structural Characteristics of Hollandite Compounds," Acta Crystallogr., B42 [3] 229-236 (1986).

[6] R. W. Cheary, "A Structural Analysis of Potassium, Rubidium and Caesium Substitution in Barium Hollandite," Acta Crystallogr., B43 28-34 (1987).

[7] S. E. Kesson and T. J. White, " $\left[\mathrm{Ba}_{\mathrm{x}} \mathrm{Cs}{ }_{\mathrm{y}}\right]\left[(\mathrm{Ti}, \mathrm{Al})^{3+}{ }_{2 x+y} \mathrm{TT}^{4+}{ }_{8-2 x-y}\right] \mathrm{O}_{16}$ Synroc-Type Hollandites. I. Phase Chemistry," Proceedings of the Royal Society of London. Series A, Mathematical and Physical Sciences 405 [1828] 73-101 (1986). 
[8] S. E. Kesson and T. J. White, " $\left[\mathrm{Ba}_{\mathrm{x}} \mathrm{Cs}_{\mathrm{y}}\right]\left[(\mathrm{Ti}, \mathrm{Al})^{3+}{ }_{2 \mathrm{x}+\mathrm{y}} \mathrm{Ti}^{4+}{ }_{8-2 \mathrm{x}-\mathrm{y}}\right] \mathrm{O}_{16}$ Synroc-Type Hollandites. II. Structural Chemistry," Proceedings of the Royal Society of London. Series A, Mathematical and Physical Sciences 408 [1835] 295-319 (1986).

[9] R. W. Cheary, "Caesium Substitution in the Titanate Hollandites $\mathrm{Ba}_{\mathrm{x}} \mathrm{Cs}_{\mathrm{y}}\left(\mathrm{Ti}_{\mathrm{y}+2 \mathrm{x}}{ }^{3+} \mathrm{Ti}_{8-2 \mathrm{x}-\mathrm{y}}{ }^{4+}\right) \mathrm{O}_{16}$ from 5 to 400 K," Acta Crystallogr., B47 325-333 (1991).

[10] S. E. Kesson and T. J. White, "Radius Ratio Tolerance Factors and the Stability of Hollandites," J. Solid State Chem., 63 122-125 (1986).

[11] G. C. C. Costa, H. Xu, and A. Navrotsky, "Thermochemistry of Barium Hollandites," J. Am. Ceram. Soc., 96 [5] 1554-1561 (2013).

[12] J. Amoroso, J. Marra, S. D. Conradson, M. Tang, and K. Brinkman, "Melt Processed Single Phase Hollandite Waste Forms for Nuclear Waste Immobilization: $\mathrm{Ba}_{1.0} \mathrm{Cs}_{0.3} \mathrm{~A}_{2.3} \mathrm{Ti}_{5.7} \mathrm{O}_{16} ; \mathrm{A}=\mathrm{Cr}$, Fe, Al,” J. Alloys \& Compounds, 584 590-599 (2014).

[13] H. Xu, G. C. C. Costa, C. R. Stanek, and A. Navrotsky, "Structural Behavior of $\mathrm{Ba}_{1.24} \mathrm{Al}_{2.48} \mathrm{Ti}_{5.52} \mathrm{O}_{16}$ Hollandite at High Temperature: An In-situ Neutron Diffraction Study,” J. Am. Ceram. Soc., DOI: 10.1111/jace.13245 (2014).

[14] A. Bystrom and A. M. Bystrom, "The Crystal Structure of Hollandite, the Related Manganese Oxide Minerals, and $\alpha-\mathrm{MnO}_{2}, "$ Acta Crystallogr., 3 [2] 146-154 (1950).

[15] J. E. Post, R. B. Von Dreele, and P. R. Buseck, "Symmetry and Cation Displacements in Hollandites: Structure Refinements of Hollandite, Cryptomelane and Priderite," Acta Crystallographica, B38 [4] 1056-1065 (1982).

[16] S. E. Kesson, "The Immobilization of Cesium in SYNROC Hollandite," Radioac. Waste Manag., 4 [3] 53-72 (1983). 
[17] M. L. Carter, A. L. Gillen, K. Olufson, E. R. Vance, "HIPed Tailored Hollandite Waste Forms for the Immobilization of Radioactive Cs and Sr", J. Am. Ceram. Soc., 92 [5] 1112-1117 (2009).

[18] A. Y. Leinekugel-le-Cocq, P. Deniard, S. Jobic, R. Cerny, F. Bart, H. Emerich, "Synthesis and Characterization of Hollandite-Type Material Intended for the Specific Containment of Radioactive Cesium", J. Solid State Chem., 179 3196-3208 (2006).

[19] R. W. Cheary, J. Kwiatkowska, "An X-ray Structural Analysis of Cesium Substitution in the Barium Hollandite Phase of Synroc", J. Nucl. Materials, 125 236-243 (1984).

[20] A. Y. Leinekugel-le-Cocq, P. Deniard, S. Jobic, E. Gautier, M. Evain, V. Aubin, F. Bart, "Structural Characterization of the Hollandite Host Lattice for the Confinement of Radioactive Cesium: Quantification of the Amorphous Phase Taking into Account the Incommensurate Modulated Character of the Crystallized Part," J. Solid State Chem, 180 322-330 (2007). [21] A. Abdelouas, S. Utsunomiya, T. Suzuki, B. Grambow, T. Advocat, F. Bart, R. C. Ewing, "Effects of ionizing radiation on the hollandite structure-type: $\mathrm{Ba}_{0.85} \mathrm{Cs}_{0.26} \mathrm{Al}_{1.35} \mathrm{Fe}_{0.77} \mathrm{Ti}_{5.90} \mathrm{O}_{16}$," Am. Mineral., 93 241-247 (2007).

[22] T. Suzuki-Muresan, J. Vandenborre, A. Abdelouas, B. Brambow, S. Utsunomiya, "Studies of (Cs, Ba)-hollandite dissolution under gamma irradiation at $95{ }^{\circ} \mathrm{C}$ and at $\mathrm{pH} 2.5,4.4$ and 8.6," J. Nucl. Materials, 419 284-290 (2011).

[23] M. L. Carter, E. R. Vance, D. R. G. Mitchell, J. V. Hanna, Z. Zhang, E. Loi, "Fabrication, Characterization, and Leach testing of Hollandite, $(\mathrm{Ba}, \mathrm{Cs})(\mathrm{Al}, \mathrm{Ti})_{2} \mathrm{Ti}_{6} \mathrm{O}_{16}, "$ J. Mater. Res., 17 [10] 2578-2589 (2002).

[24] F. Angeli, P. McGlinn, P. Frugier, "Chemical Durability of Hollandite Ceramic for Conditioning Cesium," J. Nucl. Materials, 380 [1-3] 59-69 (2008). 
[25] A. C. Larson and R. B. Von Dreele, "GSAS - General Structure Analysis System (GSAS)," Los Alamos National Laboratory Report LAUR, 86-748 (2000).

[26] P. Thompson, D. E. Cox, and J. Hastings, "Rietveld Refinements of Debye-Scherrer Synchrotron X-ray Data for $\mathrm{Al}_{2} \mathrm{O}_{3}$, , J. Appl. Crystallogr., 20, 79-83 (1987).

[27] L. W. Finger, D. E. Cox, and A. P. Jephcoat, “A Correction for Powder Diffraction Peak Asymmetry Due to Axial Divergence," J. Appl. Crystallogr., 27, 892-900 (1994).

[28] A. Navrotsky, "Progress and New Directions in High Temperature Calorimetry Revisited," Phys. Chem. Minerals, 24(3) 222-241 (1997).

[29] R. D. Shannon, "Revised Effective Ionic Radii and Systematic Studies of Interatomic Distances in Halides and Chalcogenides", Acta Crystallogr., A32 751-767 (1976).

[30] H. Xu, A. Navrotsky, M. Nyman, and T.M. Nenoff, “ Thermochemistry of Framework Titanosilicate $\mathrm{A}_{2} \mathrm{TiSi}_{6} \mathrm{O}_{15}(\mathrm{~A}=\mathrm{K}, \mathrm{Rb}, \mathrm{Cs})$, , J. Am. Ceram. Soc., 88(7) 1819-1825 (2005).

[31] J. Bularzik, A. Navrotsky, J. DiCarlo, J. Bringley, B. Scott, S. Trail, J. Solid State Chem. 93 (2), 418 (1991).

[32] Z. Zhou and A. Navrotsky, "Thermochemistry of the $\mathrm{Y}_{2} \mathrm{O}_{3}-\mathrm{BaO}-\mathrm{Cu}-\mathrm{O}$ System", J. Mater. Res., 7 (11) 292029-35 (1992).

[33] R. L. Putnam, A. Navrotsky, B. F. Woodfield, J. Boerio-Goates, and J. L.Shapiro, “Thermodynamics of Formation for Zirconolite $\left(\mathrm{CaZrTi}_{2} \mathrm{O}_{7}\right)$ from T=298.15 K to T=1500 K," J. Chem. Thermodyn., 31(2) 229-243 (1999).

[34] I. Kiseleva, A. Navrotsky, I. A. Belitsky, and B. A. Fursenko, "Thermochemistry and phase equilibria in calcium zeolites," Am. Mineral., 81 658-667 (1996). 
[35] R. A. Robie and B. S. Hemingway, "Thermodynamic Properties of Minerals and Related Substances at 298.15 K and 1 Bar (10 5 Pascals) Pressure and at Higher Temperatures," U.S. Geological Survey Bulletin No. 2131 (1995).

[36] D. D. Wagman, W. H. Evans, V. B. Parker, and R. H. Schumm, “Chemical Thermodynamic Properties of Compounds of Sodium, Potassium and Rubidium: An Interim Tabulation of Selected Values NBSIR 76-1034, 1976.

[37] A. Navrotsky, "Repeating Patterns in Mineral Energetics," Am. Mineral., 79 [7-8], 589-605 (1994).

[38] H. Xu, A. Navrotsky, M. D. Nyman, T. M. Nenoff, "Thermochemistry of microporous silicotitanate phases in the $\mathrm{Na}_{2} \mathrm{O}-\mathrm{Cs}_{2} \mathrm{O}-\mathrm{SiO}_{2}-\mathrm{TiO}_{2}-\mathrm{H}_{2} \mathrm{O}$ system," Journal of Materials Research, 15, 815-823 (2000).

[39] H. Xu, A. Navrotsky, M. D. Nyman, T. M. Nenoff, “Crystal chemistry and energetics of pharmacosiderite-related microporous phases in the $\mathrm{K}_{2} \mathrm{O}-\mathrm{Cs}_{2} \mathrm{O}-\mathrm{SiO}_{2}-\mathrm{TiO}_{2}-\mathrm{H}_{2} \mathrm{O}$ system," Microporous and Mesoporous Materials, 72, 209-218 (2004).

[40] H. Xu, A. Navrotsky, Y. Su, and M.L. Balmer, "Perovskite solid solutions along the $\mathrm{NaNbO}_{3}-\mathrm{SrTiO}_{3}$ join: Phase transitions, formation enthalpies, and implications for general perovskite energetics," Chemistry of Materials, 17(7) 1880-1886 (2005).

[41] H. Xu, A. Navrotsky, M. L. Balmer, Y. Su, "Crystal-chemical and energetic systematics of wadeite-type phases $\mathrm{A}_{2} \mathrm{BSi}_{3} \mathrm{O}_{9}(\mathrm{~A}=\mathrm{K}, \mathrm{Cs} ; \mathrm{B}=\mathrm{Si}$, Ti, Zr)," Physics and Chemistry of Minerals, 32, 426-435 (2005).

[42] D. Goldberg, "Contribution to Study of Systems Formed by Alumina and Some Oxides of Trivalent and Tetravalent Metals Especially Titanium Oxide," Rev. Int. Hautes Temper. Et Refract., 5, 181-94 (1968). 
[43] E. Takayama-Muromachi and A. Navrotsky, "Energetics of Compounds $\left(\mathrm{A}^{2+} \mathrm{B}^{4+} \mathrm{O}_{3}\right)$ with the Perovskite Structure," J. Solid State Chem., 72, 244-256 (1988).

Geochemical Journal, Vol. 13, pp. 141 to 165,1979141

Table 1. Unit-cell parameters and refinement agreement indices of substituted hollandites ${ }^{1)}$

\begin{tabular}{llllll}
\hline Phase & $a(\AA)$ & $c(\AA)$ & $V\left(\AA^{3}\right)$ & $R_{w p}(\%)$ & $R_{p}(\%)$ \\
\hline $\mathrm{Ba}_{1.18} \mathrm{Cs}_{0.21} \mathrm{Al}_{2.44} \mathrm{Ti}_{5.53} \mathrm{O}_{16}$ & $9.9826(2)$ & $2.92713(7)$ & $291.70(2)$ & 4.8 & 3.3 \\
$\mathrm{Ba}_{1.17} \mathrm{Rb}_{0.19} \mathrm{Al}_{2.46} \mathrm{Ti}_{5.53} \mathrm{O}_{16}$ & $9.9592(2)$ & $2.92391(6)$ & $290.01(1)$ & 4.4 & 3.1 \\
$\mathrm{Ba}_{1.14} \mathrm{Sr}_{0.10} \mathrm{Al}_{2.38} \mathrm{Ti}_{5.59} \mathrm{O}_{16}$ & $9.9338(2)$ & $2.91683(7)$ & $287.84(2)$ & 4.0 & 3.1 \\
\hline
\end{tabular}

${ }^{1)}$ Value in parentheses is the uncertainty of the last digit.

Table 2. Heats of drop solution $\left(\Delta \mathrm{H}_{\mathrm{ds}}\right)$ in lead borate solvent at $973 \mathrm{~K}$ and enthalpies of formation from oxides $\left(\Delta \mathrm{H}_{\mathrm{f}, \mathrm{ox}}{ }^{0}\right)$ and from elements $\left(\Delta \mathrm{H}_{\mathrm{f}, \mathrm{el}}{ }^{0}\right)$ of substituted hollandites ${ }^{1)}$

\begin{tabular}{llll}
\hline Phase & $\Delta \mathrm{H}_{\mathrm{ds}}(\mathrm{kJ} / \mathrm{mol})$ & $\Delta \mathrm{H}_{\mathrm{f}, \mathrm{ox}}{ }^{0}(\mathrm{~kJ} / \mathrm{mol})$ & $\Delta \mathrm{H}_{\mathrm{f}, \mathrm{el}}{ }^{0}(\mathrm{~kJ} / \mathrm{mol})$ \\
\hline $\mathrm{Ba}_{1.18} \mathrm{Cs}_{0.21} \mathrm{Al}_{2.44} \mathrm{Ti}_{5.53} \mathrm{O}_{16}$ & $518.2 \pm 10.4(9)$ & $-212.0 \pm 12.6$ & $-8159.7 \pm 13.7$ \\
$\mathrm{Ba}_{1.17} \mathrm{Rb}_{0.19} \mathrm{Al}_{2.46} \mathrm{Ti}_{5.53} \mathrm{O}_{16}$ & $516.5 \pm 10.4(13)$ & $-205.1 \pm 12.6$ & $-8160.0 \pm 13.7$ \\
$\mathrm{Ba}_{1.14} \mathrm{Sr}_{0.10} \mathrm{Al}_{2.38} \mathrm{Ti}_{5.59} \mathrm{O}_{16}$ & $527.4 \pm 8.5(9)$ & $-199.5 \pm 11.1$ & $-8154.5 \pm 12.3$ \\
\hline
\end{tabular}

\footnotetext{
${ }^{1)}$ Uncertainty is two standard deviation of the mean, and value in parentheses is the number of experiments.
} 
Table 3. Heats of drop solution in lead borate at $973 \mathrm{~K}\left(\Delta \mathrm{H}_{\mathrm{ds}}\right)$ and enthalpies of formation from the elements $\left(\Delta \mathrm{H}_{\mathrm{f}, \mathrm{el}}^{\mathrm{o}}\right)$ at $298 \mathrm{~K}$ of related component binary oxides

\begin{tabular}{lcc}
\hline Oxide & $\Delta \mathrm{H}_{\mathrm{ds}}(\mathrm{kJ} / \mathrm{mol})$ & $\Delta \mathrm{H}_{\mathrm{f}, \mathrm{el}}^{\mathrm{ol}}(\mathrm{kJ} / \mathrm{mol})$ \\
\hline $\mathrm{Cs}_{2} \mathrm{O}$ & $-226.1 \pm 1.8^{1)}$ & $-346.0 \pm 1.2^{6)}$ \\
$\mathrm{Rb}_{2} \mathrm{O}$ & $-216.8 \pm 1.9^{1)}$ & $-338.90 \pm 0.01^{7)}$ \\
$\mathrm{SrO}$ & $-58.5 \pm 2.2^{2)}$ & $-591.3 \pm 1.0^{6)}$ \\
$\mathrm{BaO}$ & $-91.5 \pm 1.9^{3)}$ & $-548.1 \pm 2.1^{6)}$ \\
$\mathrm{TiO}_{2}$ & $55.4 \pm 1.2^{4)}$ & $-944.0 \pm 0.8^{6)}$ \\
$\mathrm{Al}_{2} \mathrm{O}_{3}$ & $107.9 \pm 1.0^{5)}$ & $-1675.7 \pm 1.3^{6)}$ \\
\hline
\end{tabular}

1) Xu et al. (2005); ${ }^{30}$ 2) Bularzik et al. (1991); ${ }^{31}$ 3) Zhou and Navrotsky (1992); ${ }^{32}$ 4) Putnam et al. (1999); ${ }^{33}$ 5) Kiseleva et al. (1996); ${ }^{34}$ 6) Robie and Hemingway (1995); ${ }^{35}$ 7) Wagman et al. $(1976)^{36}$ 
Table 4. Thermochemical cycles used for calculation of the enthalpies of formation of $\mathrm{Ba}_{1.18} \mathrm{Cs}_{0.21} \mathrm{Al}_{2.44} \mathrm{Ti}_{5.53} \mathrm{O}_{16}$ hollandite

Enthalpy of formation of $\mathrm{Ba}_{1.18} \mathrm{Cs}_{0.21} \mathrm{Al}_{2.44} \mathrm{Ti}_{5.53} \mathrm{O}_{16}$ from the oxides at $298 \mathrm{~K}\left(\Delta H_{\text {f,ox }}^{o}\right)$

$\mathrm{Ba}_{1.18} \mathrm{Cs}_{0.21} \mathrm{Al}_{2.44} \mathrm{Ti}_{5.53} \mathrm{O}_{16}(\mathrm{~s}, 298 \mathrm{~K}) \rightarrow 1.18 \mathrm{BaO}($ soln, $973 \mathrm{~K})+0.105 \mathrm{Cs}_{2} \mathrm{O}($ soln, $973 \mathrm{~K})+$ $1.22 \mathrm{Al}_{2} \mathrm{O}_{3}$ (soln, $\left.973 \mathrm{~K}\right)+5.53 \mathrm{TiO}_{2}($ soln, $973 \mathrm{~K})$

$1.18 \mathrm{BaO}(\mathrm{s}, 298 \mathrm{~K}) \rightarrow 1.18 \mathrm{BaO}($ soln, $973 \mathrm{~K})$

$\Delta \mathrm{H}_{1}$

$0.105 \mathrm{CsO}(\mathrm{s}, 298 \mathrm{~K}) \rightarrow 0.105 \mathrm{CsO}($ soln, $973 \mathrm{~K})$

$\Delta \mathrm{H}_{2}$

$1.22 \mathrm{Al}_{2} \mathrm{O}_{3}(\mathrm{~s}, 298 \mathrm{~K}) \rightarrow 1.22 \mathrm{Al}_{2} \mathrm{O}_{3}($ soln, $973 \mathrm{~K})$

$\Delta \mathrm{H}_{3}$

$5.53 \mathrm{TiO}_{2}(\mathrm{~s}, 298 \mathrm{~K}) \rightarrow 5.53 \mathrm{TiO}_{2}(\operatorname{soln}, 973 \mathrm{~K})$

$\Delta \mathrm{H}_{4}$

$1.18 \mathrm{BaO}(\mathrm{s}, 298 \mathrm{~K})+0.105 \mathrm{Cs}_{2} \mathrm{O}(\mathrm{s}, 298 \mathrm{~K})+1.22 \mathrm{Al}_{2} \mathrm{O}_{3}(\mathrm{~s}, 298 \mathrm{~K})+5.53 \mathrm{TiO}_{2}(\mathrm{~s}, 298 \mathrm{~K}) \rightarrow$ $\mathrm{Ba}_{1.18} \mathrm{Cs}_{0.21} \mathrm{Al}_{2.44} \mathrm{Ti}_{5.53} \mathrm{O}_{16}(\mathrm{~s}, 298 \mathrm{~K}) \quad \Delta \mathrm{H}_{\mathrm{f}, \mathrm{ox}}^{0}=\Sigma \Delta \mathrm{H}_{i}(i=1-4)-\Delta \mathrm{H}_{\mathrm{ds}}$

Enthalpy of formation of $\mathrm{Ba}_{1.18} \mathrm{Cs}_{0.21} \mathrm{Al}_{2.44} \mathrm{Ti}_{5.53} \mathrm{O}_{16}$ from the elements at $298 \mathrm{~K}\left(\Delta \mathrm{H}_{f, e l}^{o}\right)$

$1.18 \mathrm{BaO}(\mathrm{s}, 298 \mathrm{~K})+0.105 \mathrm{Cs}_{2} \mathrm{O}(\mathrm{s}, 298 \mathrm{~K})+1.22 \mathrm{Al}_{2} \mathrm{O}_{3}(\mathrm{~s}, 298 \mathrm{~K})+5.53 \mathrm{TiO}_{2}(\mathrm{~s}, 298 \mathrm{~K}) \rightarrow$ $\mathrm{Ba}_{1.18} \mathrm{Cs}_{0.21} \mathrm{Al}_{2.44} \mathrm{Ti}_{5.53} \mathrm{O}_{16}(\mathrm{~s}, 298 \mathrm{~K})$

$\Delta \mathrm{H}_{\mathrm{f}, \mathrm{ox}}^{0}$

$1.18 \mathrm{Ba}(\mathrm{s}, 298 \mathrm{~K})+0.59 \mathrm{O}_{2}(\mathrm{~s}, 298 \mathrm{~K}) \rightarrow 1.18 \mathrm{BaO}(\mathrm{s}, 298 \mathrm{~K})$

$\Delta \mathrm{H}_{5}$

$0.21 \mathrm{Cs}(\mathrm{s}, 298 \mathrm{~K})+0.0525 \mathrm{O}_{2}(\mathrm{~g}, 298 \mathrm{~K}) \rightarrow 0.105 \mathrm{Cs}_{2} \mathrm{O}(\mathrm{s}, 298 \mathrm{~K})$

$\Delta \mathrm{H}_{6}$

$2.44 \mathrm{Al}(\mathrm{s}, 298 \mathrm{~K})+1.83 \mathrm{O}_{2}(\mathrm{~g}, 298 \mathrm{~K}) \rightarrow 1.22 \mathrm{Al}_{2} \mathrm{O}_{3}(\mathrm{~s}, 298 \mathrm{~K})$

$\Delta \mathrm{H}_{7}$

$5.53 \mathrm{Ti}(\mathrm{s}, 298 \mathrm{~K})+5.53 \mathrm{O}_{2}(\mathrm{~g}, 298 \mathrm{~K}) \rightarrow 5.53 \mathrm{TiO}_{2}(\mathrm{~s}, 298 \mathrm{~K})$

$\Delta \mathrm{H}_{8}$

$1.18 \mathrm{Ba}(\mathrm{s}, 298 \mathrm{~K})+0.21 \mathrm{Cs}(\mathrm{s}, 298 \mathrm{~K})+2.44 \mathrm{Al}(\mathrm{s}, 298 \mathrm{~K})+5.53 \mathrm{Ti}(\mathrm{s}, 298 \mathrm{~K})+8 \mathrm{O}_{2}(\mathrm{~g}, 298 \mathrm{~K})$

$\rightarrow \mathrm{Ba}_{1.18} \mathrm{Cs}_{0.21} \mathrm{Al}_{2.44} \mathrm{Ti}_{5.53} \mathrm{O}_{16}(\mathrm{~s}, 298 \mathrm{~K})$ $\Delta \mathrm{H}_{\mathrm{f}, \mathrm{el}}^{0}=\Delta \mathrm{H}_{\mathrm{f}, \mathrm{ox}}^{0}+\Sigma \Delta \mathrm{H}_{i}(i=5-8)$ 


\section{Figure captions}

Fig. 1 (a) Structural drawing of hollandite, $\mathrm{A}_{\mathrm{x}}\left(\mathrm{Ti}^{4+}, \mathrm{B}\right)_{8} \mathrm{O}_{16}\left(\mathrm{~A}=\mathrm{Ba}^{2+}, \mathrm{Cs}^{+}, \mathrm{Rb}^{+}, \mathrm{Sr}^{2+}\right.$ etc.; $\mathrm{B}=\mathrm{Al}^{3+}, \mathrm{Fe}^{3+}$ etc.), with its c-axis being vertical; (b) Projection of the structure along $\mathbf{c}$ showing the cross-section of the tunnels. Blue octahedra represent $\left[\left(\mathrm{Ti}^{4+}, \mathrm{B}\right) \mathrm{O}_{6}\right]$ units, pink balls represent $\mathrm{A}$ cations, and blue lines outline unit cells. The structure was drawn based on the structural parameters of $\mathrm{Ba}_{1.24} \mathrm{Al}_{2.48} \mathrm{Ti}_{5.52} \mathrm{O}_{16}$ [13] using the CrystalMaker software. Note for each pair of Ba sites shown in (a), only one of them can be occupied by Ba.

Fig. 2 Back-scatted electron images of the samples (a) $\mathrm{Ba}_{1.18} \mathrm{Cs}_{0.21} \mathrm{Al}_{2.44} \mathrm{Ti}_{5.53} \mathrm{O}_{16}$, (b) $\mathrm{Ba}_{1.17} \mathrm{Rb}_{0.19} \mathrm{Al}_{2.46} \mathrm{Ti}_{5.53} \mathrm{O}_{16}$, and (c) $\mathrm{Ba}_{1.14} \mathrm{Sr}_{0.10} \mathrm{Al}_{2.38} \mathrm{Ti}_{5.59} \mathrm{O}_{16}$. Dark areas correspond to pores. The uniform intensity distribution across sample grains indicates the occurrence of a single phase.

Fig. 3 Fitted synchrotron XRD patterns of (a) $\mathrm{Ba}_{1.18} \mathrm{Cs}_{0.21} \mathrm{Al}_{2.44} \mathrm{Ti}_{5.53} \mathrm{O}_{16}$, (b) $\mathrm{Ba}_{1.17} \mathrm{Rb}_{0.19} \mathrm{Al}_{2.46} \mathrm{Ti}_{5.53} \mathrm{O}_{16}$, and (c) $\mathrm{Ba}_{1.14} \mathrm{Sr}_{0.10} \mathrm{Al}_{2.38} \mathrm{Ti}_{5.59} \mathrm{O}_{16}$. Data are shown as red plus signs, and the solid green curve is the best fit to the data. Black tick marks below the pattern show the positions of allowed reflections, and the lower pink curve represents the difference between the observed and calculated profiles. Note that the weak and broad superlattice peaks in the $2 \theta$ ranges of $5^{\circ}-6^{\circ}$ and $6.9^{\circ}-7.3^{\circ}$ were excluded for the refinements.

Fig. $4 \quad$ Variations of (a) cell parameters $a$, (b) $c$, and (c) cell volume $V$ of hollandite phases, $\mathrm{Ba}_{1.18} \mathrm{Cs}_{0.21} \mathrm{Al}_{2.44} \mathrm{Ti}_{5.53} \mathrm{O}_{16}, \mathrm{Ba}_{1.17} \mathrm{Rb}_{0.19} \mathrm{Al}_{2.46} \mathrm{Ti}_{5.53} \mathrm{O}_{16}$ and $\mathrm{Ba}_{1.14} \mathrm{Sr}_{0.10} \mathrm{Al}_{2.38}$ $\mathrm{Ti}_{5.59} \mathrm{O}_{16}$, as a function of ionic radii of $\mathrm{Cs}^{+}, \mathrm{Rb}^{+}$and $\mathrm{Sr}^{2+}$ (in an eight-oxygen coordination). 
Fig. 5 Variations of (a) enthalpies of formation from the constituent oxides at $298 \mathrm{~K}$ $\left(\Delta \mathrm{H}_{\mathrm{f}, \mathrm{ox}}^{\mathrm{o}}\right)$ and (b) enthalpies of reactions (1), (2) and (3) (see text) for the hollandite phases, $\mathrm{Ba}_{1.18} \mathrm{Cs}_{0.21} \mathrm{Al}_{2.44} \mathrm{Ti}_{5.53} \mathrm{O}_{16}, \mathrm{Ba}_{1.17} \mathrm{Rb}_{0.19} \mathrm{Al}_{2.46} \mathrm{Ti}_{5.53} \mathrm{O}_{16}$ and $\mathrm{Ba}_{1.14} \mathrm{Sr}_{0.10} \mathrm{Al}_{2.38} \mathrm{Ti}_{5.59} \mathrm{O}_{16}$, as a function of ionic radii of $\mathrm{Cs}^{+}, \mathrm{Rb}^{+}$and $\mathrm{Sr}^{2+}$. 
(a)

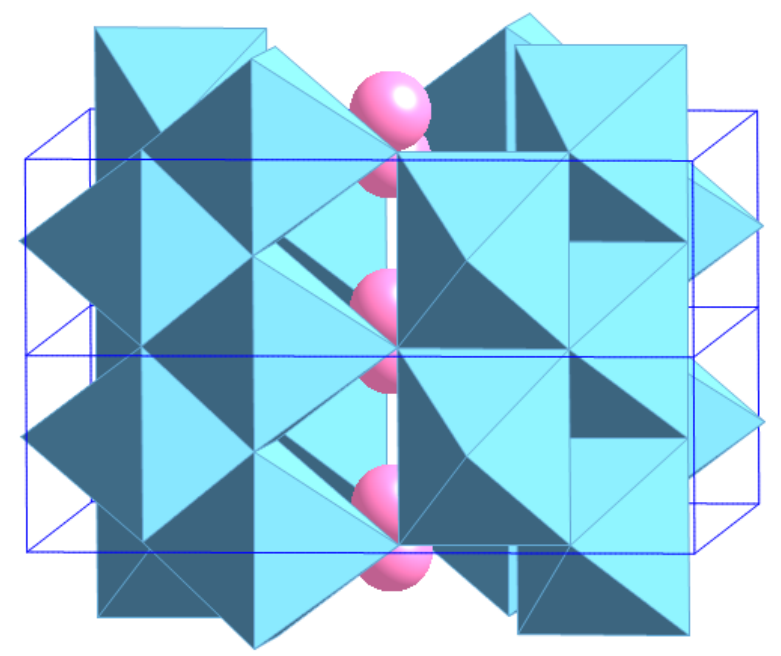

(b)

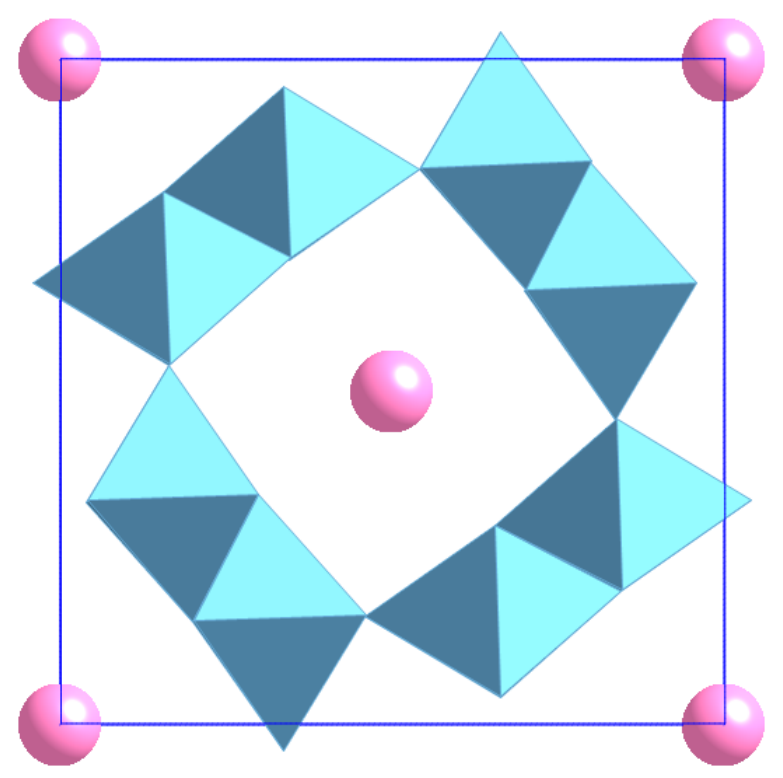

Fig. 1 

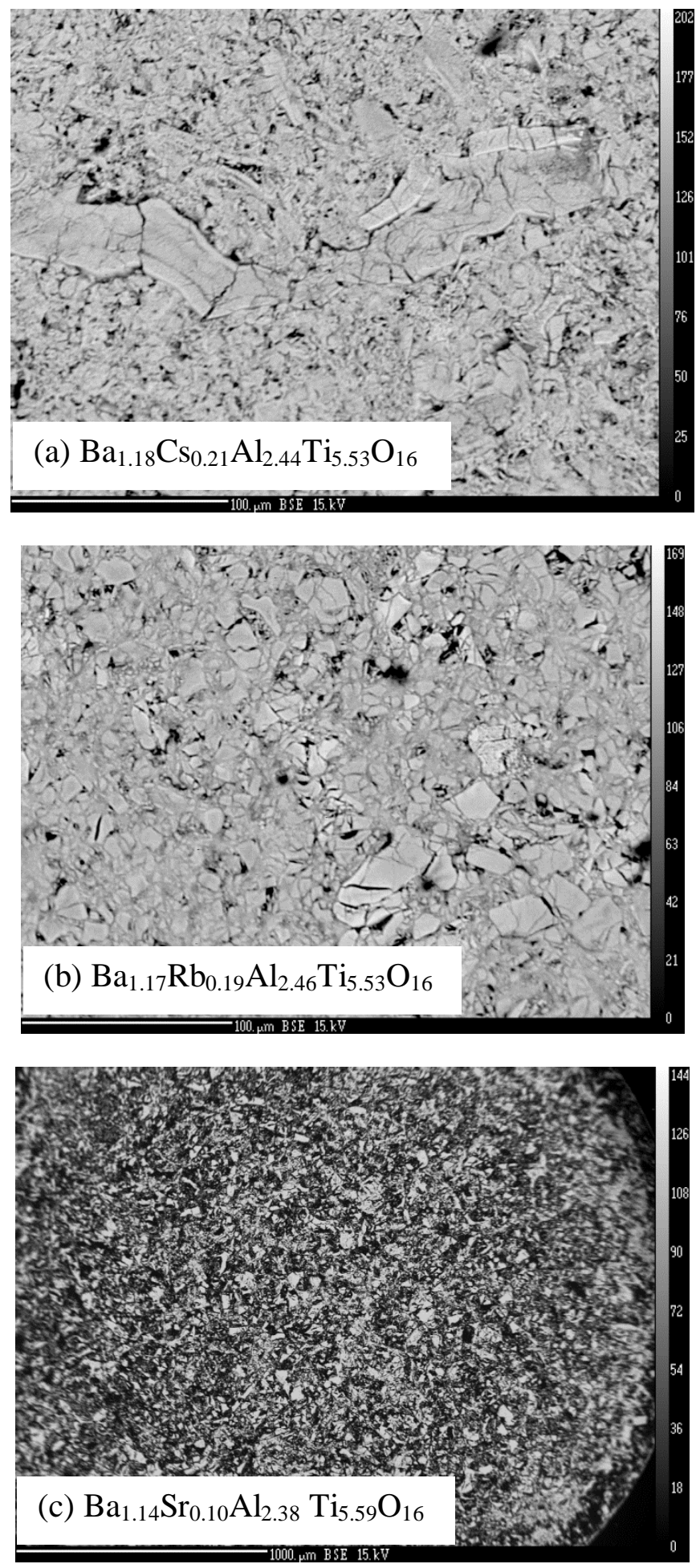

Fig. 2 


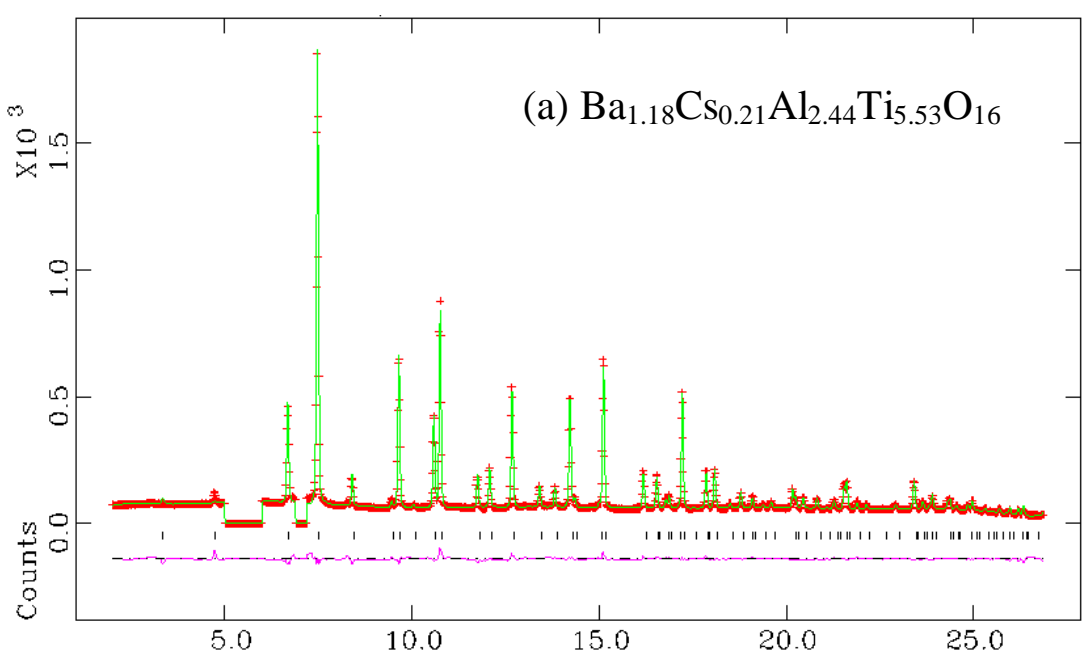

$2 \Theta, \operatorname{deg}$

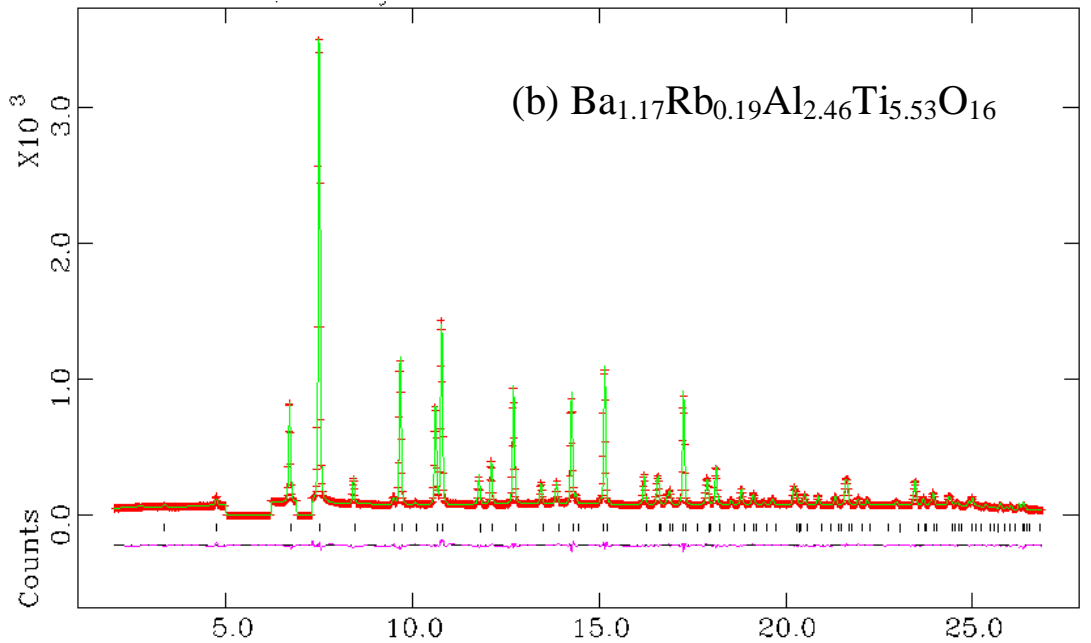

$2 \Theta, \operatorname{deg}$

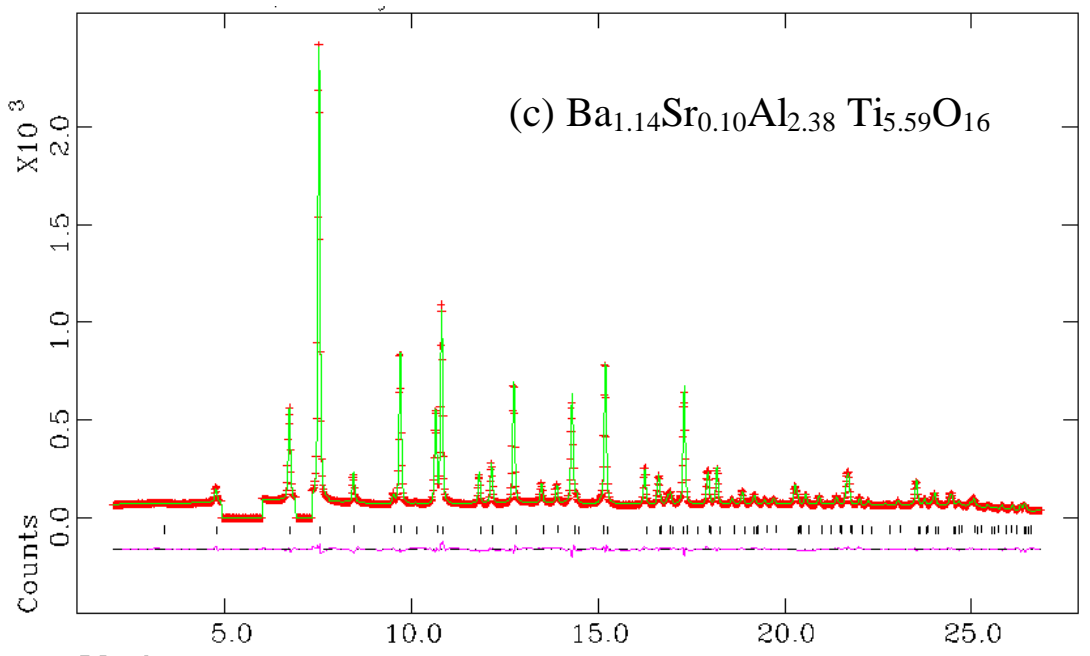

$2 \Theta$, deg

Fig. 3 

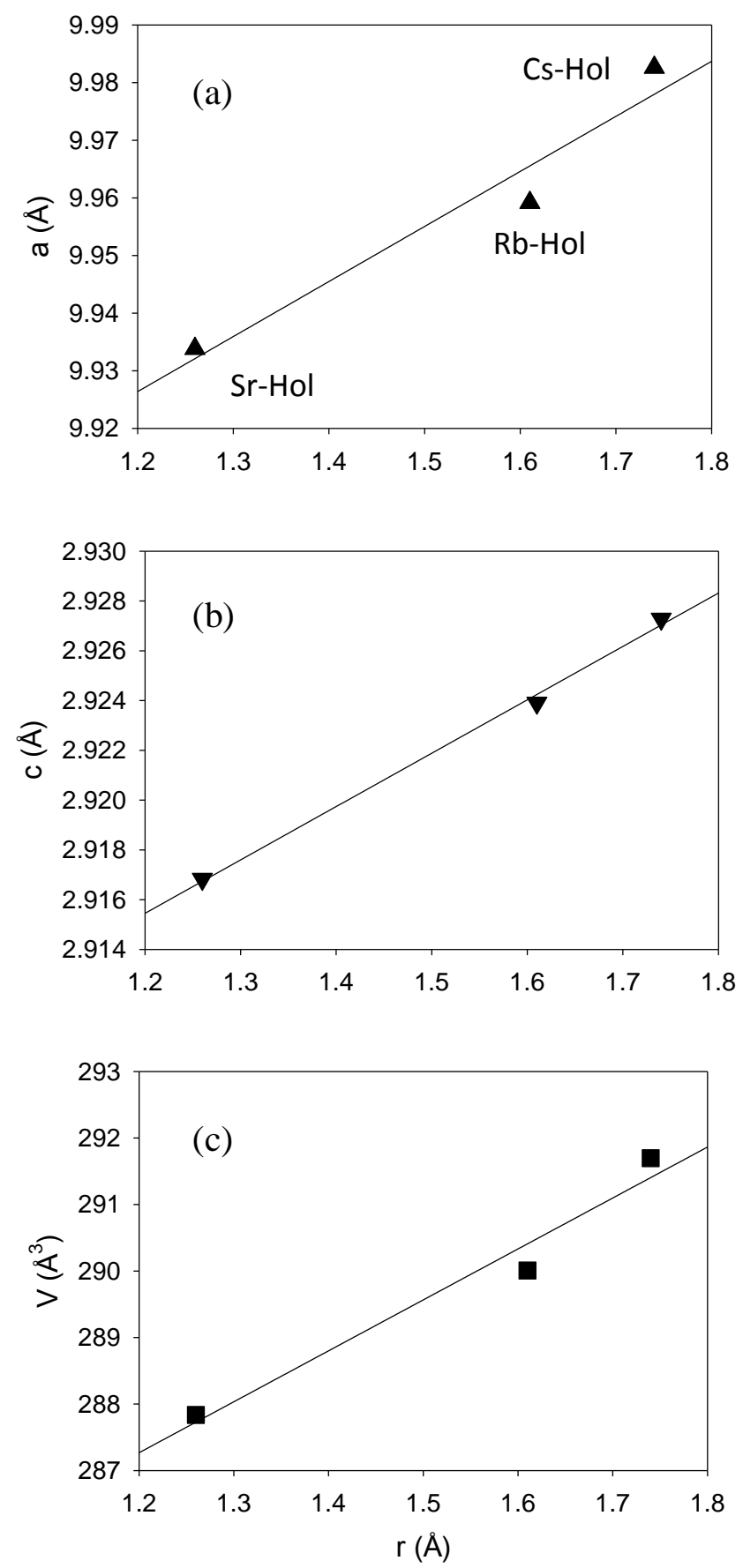

Fig. 4 

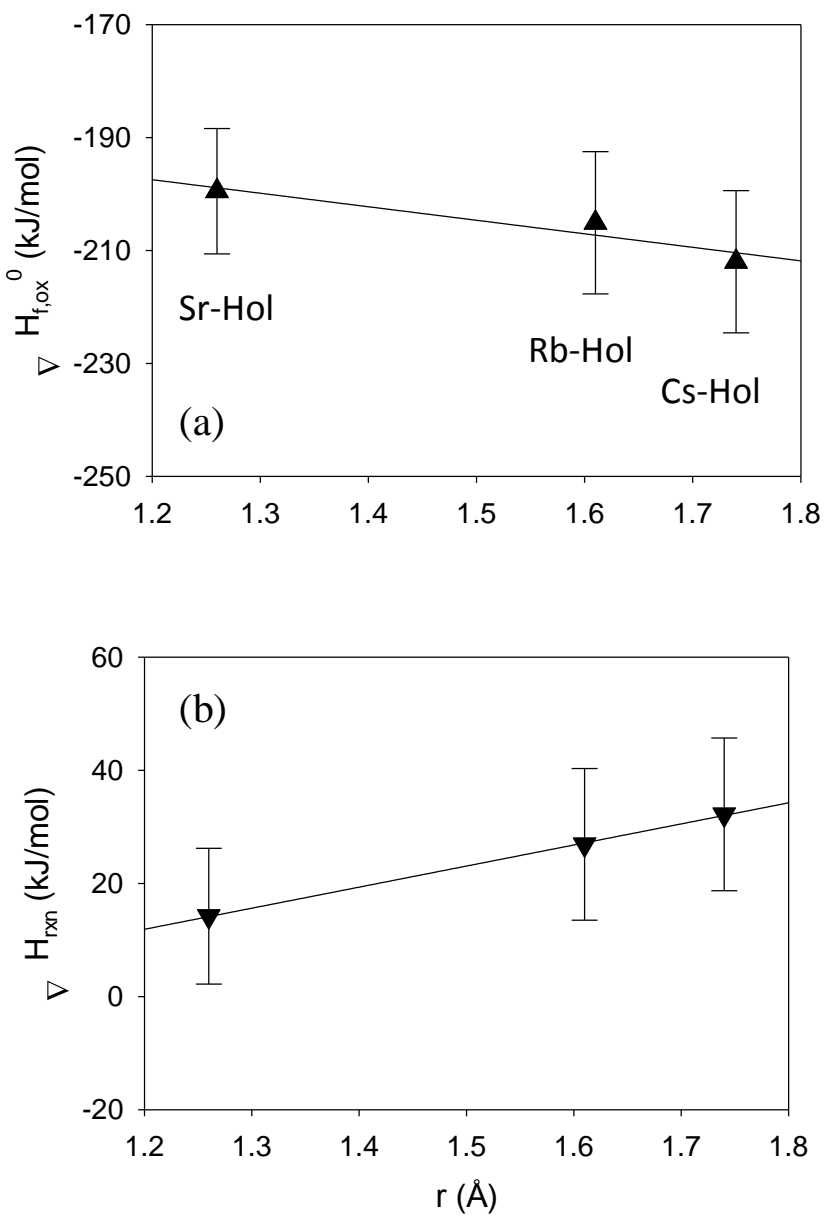

Fig. 5 